911.3

\author{
- озинський \\ ьвівський н ціон льний університет імені в н \\ вул. . орошенк , 41, м. ввів, 79000, кр їн , тел. 239-47-69
}

пис но ст новлення т розвиток к федри геогр фії кр їни ьвівського н ціон льного університету імені в н р нк, першої к федри т кого спрямув ння з всю історію існув ння різних геогр фічних інституцій в кр їні. иділено т $\mathrm{cx}$ р ктеризов но чотири ет пи у розвитку к федри геогр фії кр їни. ро н лізов но суч сний ст н к федри, головні ії н укові здобутки, т кож н йв жливіші н прями н укових досліджень.

лючові слов : геогр фія, к федр геогр фії кр їни, ет пи розвитку, н прями н укових досліджень.

федру геогр фії кр їни н геогр фічному ф культеті ьвівського н ціон льного університету імені в н р нк створено у тр вні 1990 р. отреб в появі т кої к федри з'явил ся передусім ун слідок швидкого зрост ння н прикінці 80-х років ст. в кр їні з цік вленості геогр фічним укр їнозн вством, що було зумовлено ктивіз цією н ціон льно-культурних процесів з вдяки поступовій демокр тиз ції суспільного життя в тодішньому дянському оюзі. федр геогр фії кр їни у ьвівському університеті бул першою к федрою т кого спрямув ння з всю історії існув ння різних геогр фічних інституцій в кр їні. же восени 1990 р. створено к федру геогр фії кp їни і к ртогр фії н геогр фічному ф культеті ернівецького держ вного університету ім. . едькович . продовж декількох н ступних років к федри з т кою н звою виникли в інших відомих в кр їні центр х геогр фічної освіти: ернополі (1992), иєві (1995), десі (1996), елітополі (1996).

ершу в держ ві к федру геогр фії кр їни створено з метою поглиблення геогр фічних досліджень природи, н селення т господ рств кр їни, підготовки висококв ліфіков них ф хівців-геогр фів для середніх і вищих н вч льних 3 кл дів. сновником к федри т іï з відув чем упродовж м йже 20 років (до червня 2009 р.) був профеcop, доктор геогр фічних н ук . ст вний, відомий укр їнський геогр ф, л уре т премії імені . . ліхтер кр їни, дійсний член укового тов риств ім. евченк, очесний член кр їнського геогр фічного тов риств, к демік к демії н ук ищої школи кр їни.

рофесор . ст вний є вихов нцем ьвівської геогр фічної школи. ін н родився у с. обринів ог тинського р-ну в но- р нківської обл. 27 березня 1929 р. 1946-1951 рр., після з кінчення ог тинського педучилищ , н вч вся н геогр фічному ф культеті ьвівського держ вного університету імені в н $\mathrm{p}$ нк . годом пр цюв в н уковим співробітником відділу економіки нституту суспільних н ук ьвівської філії (1951-1953), ред ктором сільськогоспод рського відділу обл сної г зети

(c) озинський ., 2012 
“ ільн кр їн ” (1953-1955), доцентом геогр фічного ф культету ьвівського університету (1955-1961), доцентом, професором т з відув чем к федри економічної геогр фiї ьвівського торговельно-економічного інституту (1961-1974). 1957 р. отрим в н уковий ступінь к ндид т економічних н ук, у 1971 р. ст в доктором геогр фічних н ук, 1972 р. отрим в учене зв ння професор . 1974 р. . ст вний переїх в до иєв , де пр цюв в з відув чем відділу проблем економіки р йонів ди по вивченню продуктивних сил кр їни ․ 1988 р. повернувся до ьвов , і до 1990 р. очолюв в к федру економічної т соці льної геогр фії ьвівського університету.

історії к федри геогр фії кр їни від ч су їі з снув ння й до сьогодні виділяють декільк ет пів. ерший ет п - ст новлення к федри (1990-1996). цей період н к федрі формув вся викл д цький персон л, визн ч лися головні н прями н укових досліджень. ерсон льний скл д к федри поповнюв вся з н уковців ьвов , пр цівників ьвівського університету й інших н вч льних і н укових уст нов міст . окрем , 3 ьвівського лісотехнічного інституту проф. . ст вний з просив викл д ти н к федрі геогр фії кр їни доц. . рохимчук , з ьвівського торговельно-економічного інституту (тепер ьвівськ комерційн к демія) - доц. . ед шківську, відомого в

хідній кр їні ф хівця з рекре ційної геогр фії, з узею н родної рхітектури й побуту у ьвові - відомого укр їнського кр єзн вця . нилюк , $з$ нституту економіки кр їни (тепер нститут регіон льних досліджень кр їни) - перспективного н уковця-геогр ф . ністрянського.

1992 р. при к федрі відкрито спір нтуру з спеці льністю “економічн й соці льн геогр фія”, 1994 р. здійснено перший випуск студентів к федри геогр фії кр їни. оступово уст лилися головні н прями геогр фічних досліджень к федри: геогр фія н селення, етногеогр фія, історичн геогр фія, політичн геогр фія, рекре ційн геогр фія, геогр фія туризму, геогр фічне кр єзн вство.

к федрі геогр фії кр їни 1991 р. з поч тков но вид ння серії укр їнозн вчих пр ць під рубрикою “ родозн вчі студії”. ершими в серії вийшли пр ці проф. . ст вного, присвячені східній і з хідній укр їнській ді спор м, укр їнським етнічним землям, н селенню кр їни, т кож моногр фія . ністрянського “ ордони кр їни. ериторі льно- дміністр тивний устрій” (1992).

ч с створення к федри в жливою проблемою геогр фічної освіти в кр їні був низькій рівень з безпеченості студентів і школярів ф ховими підручник ми і н вч льними посібник ми з геогр фії кр їни, їхня н дмірн ідеологіз ція т ч сто невисок якість. - ст вний, очоливши новостворену к федру геогр фії кр їни, передусім зосередив ув гу н вирішенні цієї проблеми. е н прикінці 80-х років ст. він підготув в н вч льний посібник для студентів геогр фічних ф культетів університетів і педінститутів під н звою “ еогр фія кр їни” (вийшов у 1990 р.). 1994 р. з’явився новий, великого форм ту, н вч льний посібник для студентів вищих н вч льних $з$ кл дів “ еогр фія кр їни” у двох книг х, який н 6 г то років ст в н стільною книгою для всіх ш нув льників геогр фії в кр їні.

1994 р. н геогр фічному ф культеті відкрито спеці лізов ну р ду із з хисту дисерт цій н здобуття н укового ступеня к ндид т геогр фічних н ук, головою якої ст в проф. . с ст вний. 1995 р. н к федрі геогр фії кр їни відбувся перший з хист дисерт ції - . ністрянський з хистив пр цю н тему “ олітико- дміністр тивний устрій кр їни (геогр фічні проблеми формув ння і вдоскон лення)”.

ругий ет п у розвитку к федри геогр фії кр їни -1997-2002 pp. 1997 р. н геогр фічному ф культеті розпоч л ся підготовк ф хівців з менеджменту туризму. и- 
пускною з цієї спеці ліз ції ст л к федр геогр фії кр їни. озпоч лося швидке зрост ння кількості студентів, т кож викл д цького скл ду к федри. ороку з пров джув ли чим ло нових н вч льних дисциплін. к федрі, т й з г лом н ф культеті, н були нового розвитку н укові туризмозн вчі дослідження. 2002 р. к федр геогр фії кр їни здійснил перший випуск ф хівців з менеджменту туризму.

ей же період супроводжув вся стрімким зрост нням кількості з хистів к ндид тських дисерт цій спір нт ми й здобув ч ми к федри. окрем , в 1997 р. відбувся 3 хист дисерт ції спір нт к федри - врук (тем - “ уцули кр їнських рп т (етногеогр фічне дослідження)". 1998 р. дисерт цію н здобуття н укового ступеня к ндид т історичних н ук з хистив ст. викл д ч . нилюк (“ р диційне житловогоспод рське будівництво кр їнського олісся (ст новлення т еволюція))”. н ступні роки дисерт ційні роботи з хистили . уреляк (“ке їнськ ді спор р морощини (етногр фічне дослідження)”, 2000), . ов льчук (“ еогр фія релігій в кp їні”, 2000), . уч бський (“ елігійн сфер обл сного регіону: тр нсформ ція і територі льн орг ніз ція (н м тері л х ьвівської обл сті)”, 2000), . озинський (“ тнічний скл д міського н селення личини (історико-геогр фічне дослідження)”, 2000), . ливк (“ тногеогр фічне дослідження ойківщини”, 2002), ньків (“ емогеогр фічний розвиток гірських р йонів кр їнських $\quad$ рп т”, 2002). підст ві цих дисерт цій, т кож з г лом 3 результ т ми н укової діяльності викл д чів к федри опубліков но декільк цік вих моногр фій і н вч льних посібників.

ст вний продовжув в роботу н д н пис нням н вч льної літер тури з геогр фії кр їни. прикінці 90-х років ст. він підготув в і опубліков в підручники для з г льноосвітніх шкіл з фізичної геогр фії кр їни (для 8-го кл су) т економічної і соці льної геогр фії кр їни (для 9-го кл су). ерше вид ння їх з'явилося у 1999 р. годом їх перекл дено російською, т кож румунською, угорською, польською мов ми для шкіл з мов ми викл д ння н ціон льних меншин. 1999 р. проф. . ст вний н 3 мовлення рв рдського університету ( ) підготув в 24 ст тті з геогр фії кр їни для опублікув ння їх в укр їнозн вчій енциклопедії університету.

. ністрянський в кр їнському ільному університеті ( юнхен) 1999 р. $з$ хистив докторську дисерт цію “ кр їн в геополітичному вимірі”.

озвиток туристичної освіти н геогр фічному ф культеті ьвівського університету н поч тку ст. сформув в потребу в к федрі, як 6 спеці лізув л ся н підготовці студентів цього профілю. січні 2003 р. вн слідок поділу к федри геогр фії кр їни було створено к федру туризму. новостворену к федру перейшли пр цюв ти викл д чі к федри геогр фії кр їни . т ляк, . ов льчук, . льськ , . ньків, . енюк, . утинський.

ступний ет п у розвитку к федри - 2003-2008 рр. (див. рис.). цей період к федр стрімко н рощув л н укові здобутки попередніх років.

2006 p. . ністрянський 3 хистив дисерт цію н здобуття н укового ступеня доктор геогр фічних н ук (тем - “ тнополітичн геогр фія кр їни: проблеми теорії, методології, пр ктики”). ого ж року . озинський ст в переможцем конкурсу н визн чення ліпшого молодого н уковця ьвівського н ціон льного університету “" олодий н уковець університету 2005 року”. . врук опублікув л одну з н йліпших у суч сній укр їнській н уці пр цю про уцульщину - моногр фію “ уцули кр їнських

рп т (етногеогр фічне дослідження)”, як швидко ст л бібліогр фічною рідкістю. хистили дисерт ції н здобуття н укового ступеня к ндид т геогр фічних н ук викл д чі к федри . рицюк (“ емогеогр фічн ситу ція укр їнсько-польського пог- 
p ниччя”, 2005), . тецюк (“ уристичний комплекс рп тського регіону кр їни: структур т територі льн орг ніз ція”, 2006), . бінськ (“ іноче н селення регіону: суспільно-геогр фічні спекти (н м тері л х ьвівської обл сті)”, 2007).

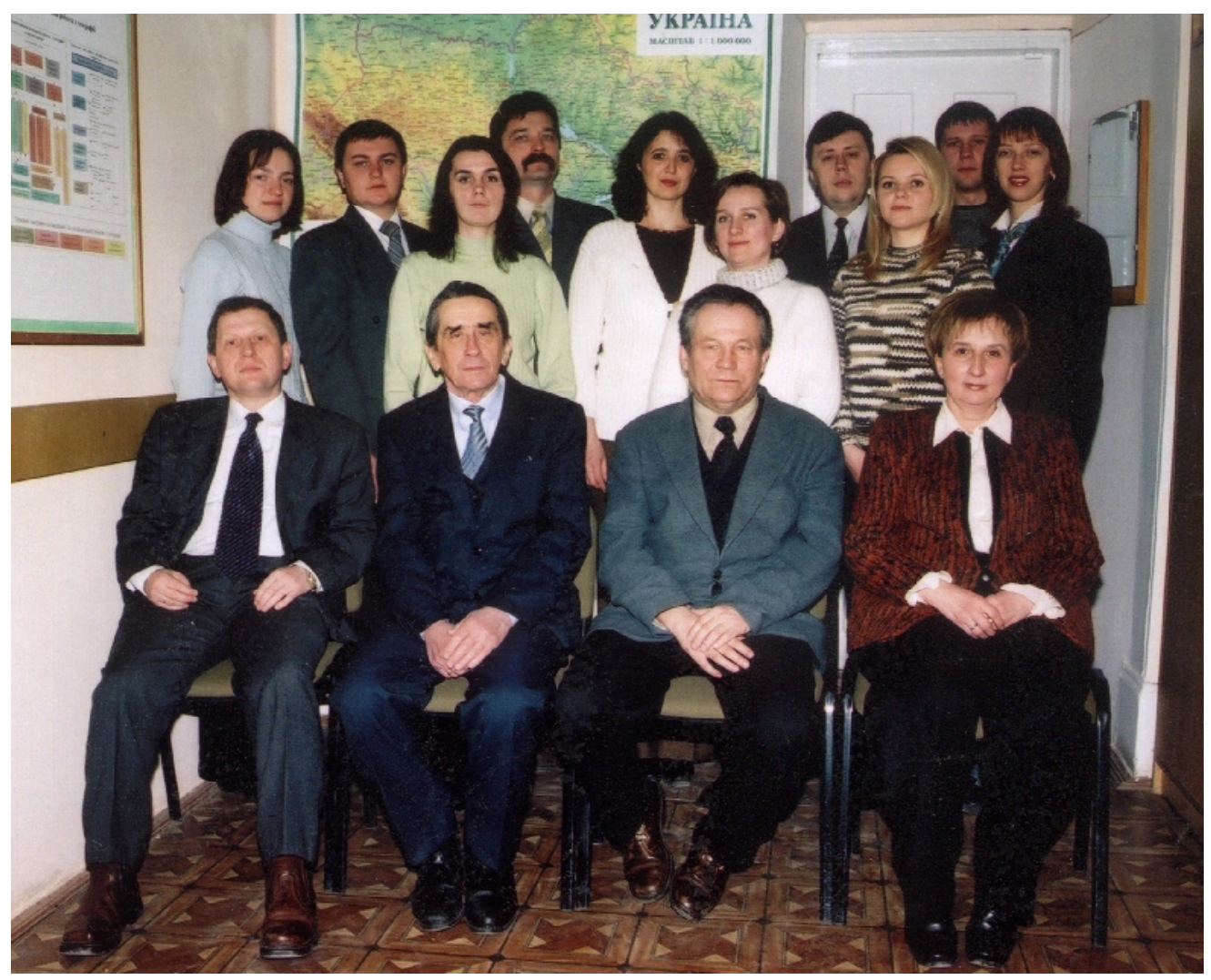

федр геогр фії кр їни (літо 2005): сидять злів н $\quad$ кр во: доц. . ністрянський, проф. . ст вний (з відув ч к федри), доц. . нилюк, ст. л б. . нцір. тоять: сп. . інкевич, сп. . нько, ст. л б. . ілевич, доц. . йЦ р, доц. . врук, ст. л б. . ністрянськ, доц. . озинський, с. . рицюк, сп. . овгич, с. тецюк.

поч тку 2004 р. професор . ст вний спільно з проф. . усінським опублікув в польською мовою у вид вництві рш вського університету моногр фію “ кр їн (природ , н селення, господ рство)”. 2006 р. з'явил ся нов його моногр фія, присвячен проблем м депресивності в кр їні.

икл д чі к федри вид ли низку цік вих т оригін льних моногр фій, н вч льних посібників і підручників, б г то у чому нов торських для геогр фічної н уки в кp їни: озинський . . тнічний скл д н селення ьвов (у контексті суспільного розвитку личини) ( ьвів, 2005); ністрянський . . тнополітичн геогр фія кp їни: проблеми теорії, методології, пр ктики ( ьвів, 2006); ністрянський . . тногеогр фія кр їни ( ьвів, 2008) й ін. 
2009 р. поч вся н ступний ет п діяльності к федри геогр фії кр їни. червні 2009 р. $з$ ст ном здоров'я з к федри звільнився іiї з сновник, проф. . ст вний. иконув ти обов'язки з відув ч к федри геогр фії призн чено доц. . озинського, н весні 2010 р. його обр но з відув чем к федри. ого ж року . озинський з хистив дисерт цію н здобуття н укового ступеня доктор геогр фічних н ук (тем - “ тномовн геогр фія кр їни”), спір нт . клярськ - дисерт цію н здобуття н укового ступеня к ндид т геогр фічних н ук (тем - “ олітико-геогр фічні процеси в прикордонних р йон х к рп тської і ернівецької обл стей”). 2011 р. відбувся з хист к ндид тської дисерт ції . л пчук (тем - “ уристично-рекре ційні ресурси ьвівської обл сті: територі льн диференці ція, оцінк , н прямки використ ння”). ийшли нові н вч льні посібники . ст вного, - ністрянського, моногр фія . клярської.

ьогодні н к федрі геогр фії кр їни пр цюють десять осіб: вісім викл д чів (двоє докторів ( · ністрянський, · озинський), шість к ндид тів ( · йц р, · суляк, бінськ , . врук, . клярськ , . тецюк) геогр фічних н ук) і двоє ст рших л бор нтів ( . ужинськ , . ністрянськ ) (див. вкл. 6).

федр випуск є ф хівців зі спеці льності “ еогр фія” з присвоєнням кв ліфік цій “б к л вр”, “спеці ліст”, “м гістр”. он з безпечує викл д ння низки норм тивних дисциплін і спецкурсів для спеці льностей “геогр фія” і “менеджмент” геогр фічного ф культету, проводить керівництво н вч льними, виробничими, пед гогічними пр ктик ми, курсовими, дипломними т м гістерськими робот ми. ри к федрі функціонують спір нтур т доктор нтур .

ч су з снув ння к федри і до сьогодні з хищено дві докторські, близько 20 к ндид тських дисерт цій з спеці льністю “економічн і соці льн геогр фія”. рім ьвівського н ціон льного університету, чим ло колишніх студентів, спір нтів, викл д чів к федри пр цюють в інших вищих н вч льних і н укових 3 кл д х ьвов, иєв , в но- $\mathrm{p}$ нківськ, т кож у умунії. они продовжують н укову роботу не лише в г лузі геогр фії, серед них є доктори і к ндид ти економічних, юридичних н ук, н ук держ вного упр вління.

ровідні н уковці к федри, доктори н ук . ністрянський і . озинський, є член ми спеці лізов них р д із з хисту дисерт цій з геогр фічних т економічних н ук, член ми ред кційних колегій н укових журн лів з геогр фії т споріднених н ук. уковці к федри підтримують зв'язки 3 н уковими орг ніз ціями ольщі, ілорусі, осії, імеччини й інших кр їн.

икл д чі к федри з безпечують т кі норм тивні н вч льні курси: “ кономічн і соці льн геогр фія кр їни”, “ кономік кр їни”, “ етодик викл д ння геогр фії”, “ етодик викл д ння економіки”, “ селення кр їни”, “ ізичн геогр фія кp їни”. ля студентів, що спеці лізуються н к федрі, з пров джено чим ло спецкурсів: “ еогр фія культури в кр їні”, “ еогр фія міжн родних зв’язків кр їни”, “ еогр фія погр ничних 3 кр їною держ в”, “ еогр фія поселень в кр їні”, “ еогр фія релігій в кр їні”, “ еогр фія туризму в кр їні з основ ми туризмозн вств ”, “ тногеогр фія кр їни”, “сторичн геогр фія кр їни”, “ уч сні теоретичні т прикл дні проблеми геогр фії кр їни”, “ опонімік кр їни” й ін.

к федрі функціонує к бінет методики н вч ння геогр фії й економіки (створено в 2001 р.), яким керує доц. . врук. ньому зосереджено пон д 900 одиниць н вч льно-методичних м тері лів і з собів, які студенти використовують під ч с підготовки до пр ктичних робіт з методики н вч ння геогр фії й економіки, т кож під ч с проходження пед гогічних пр ктик у з г льноосвітніх н вч льних 3 кл д х. к бінеті 
студенти т викл д чі можуть переглянути відеоз писи уроків, користув тися н йновішими методичними посібник ми, електронними текст ми лекцій із методики н вч ння геогр фії й економіки, мультимедійними підручник ми для з г льноосвітньої школи, електронними шкільними тл с ми тощо. бінет є б зовим для проведення курсів підвищення кв ліфік ції вчителів геогр фії при нституті післядипломної освіти ьвівського н ціон льного університету імені в н $\mathrm{p}$ нK .

укові дослідження к федри тр диційно пов'яз ні з н уковим н прямом геогр фічного укр їнозн вств, що з поч тков ний проф. . ст вним дн к перелік н прямів н укових досліджень викл д чів н спр вді є зн чно ширшим і охоплює різном нітні г лузі суспільної геогр фії.

ровідними н прям ми н укової діяльності к федри геогр фії кр їни є: етногеогр фія кр їни (у цьому н прямі пр цюють . ністрянський, . врук, . озинський); політичн геогр фія і геополітик ( . ністрянський, . клярськ ); геогр фія н селення і геогр фія поселень в кр їні ( . суляк, . бінськ , . ністрянськ ); геогр фія туризму й рекре ційн геогр фія кр їни ( . озинський, . тецюк); геогр фічне кр єзн вство ( . врук). рім цього, пров дять дослідження з фізичної геогр фії кр їнських рп т і риму ( . йц p); історичної геогр фії кр їни ( . ністрянський, озинський); методики і технології н вч ння геогр фії ( . врук, . бінськ ).

тнічн геогр фія. тногеогр фічну проблем тику н к федрі з поч тков но ще в 90-х рок х ст., тобто з перших років існув ння к федри геогр фії кр їни у пр цях . ст вного й . ністрянського. оді ж для студентів з пров джено спецкурс “ тногеогр фія кр їни”. н укових пр цях . ністрянського і . озинського етногеогр фічн скл дов поєдн н з дослідженнями із політичної й історичної геогр фії.

. озинський у моногр фії “ тнічний скл д н селення ьвов (в контексті з г льного суспільного розвитку личини)” ( ьвів, 2005) викон в історико-геогр фічне дослідження формув ння й дин міки етнічного скл ду н селення ьвов від ч су з снув ння міст й до суч сності. 2006 р. ністрянський уперше в історії укр їнської геогр фії опублікув в н вч льний посібник “ тногеогр фія кр їни”.

тномовний н прям в етнічній геогр фії, розвив є доц. . озинський, він 2008 р. опублікув в моногр фію “ овн ситу ція в кр їні: суспільно-геогр фічний погляд”, де розроблено теоретичні й методичні основи суспільно-геогр фічного дослідження мовної ситу ції. 2011 р. н уковець скл в к рту мовного скл ду н селення кр їни ст ном н Поч тоК ст.

олітичн геогр фія і геополітик • озвиткові цього н пряму к федр геогр фії кр їни передусім з вдячує . ністрянському, який сьогодні є визн ним в кр їні н уковцем політико-геогр фом і геополітиком. чений розробив теоретико-методологічні т методичні з с ди дослідження дміністр тивно-територі льного устрою, формув ння й функціонув ння держ вних кордонів, розкрив з кономірності їхнього впливу н суспільно-геогр фічне середовище, обгрунтув в з с ди конструктивної зрівнов женої геополітики, розробив методику вз ємопов'яз ного дослідження етногеогр фічних і територі льно-політичних вз ємин, н з с д х якої дослідив х р ктер етнополітичних вз ємозв'язків н території кр їни. . ністрянський є втором численних пр ць з політичної геогр фії й геополітики: “ ордони кр їни. ериторі льно- дміністр тивний устрій” ( ьвів, 1992), “ кр їн в політико-геогр фічному вимірі” ( ьвів, 2000), “ еополітичні доктрини і підходи: критичний н ліз методології” ( ьвів, 2003), тнополітичн геогр фія кр їни: проблеми теорії, методології, пр ктики ( ьвів, 
2006), “ олітичн геогр фія т геополітик кр їни” ( ернопіль, 2010), “ еополітик ” ( ьвів, 2011). олітико-геогр фічне спрямув ння м ють т кож н укові пр ці . клярської.

еогр фія туризму й рекре ційн геогр фія. ей н уковий н прям т кож 3 поч тков но ще в перші роки існув ння к федри, коли . ст вним з просив викл д ти . . ед шківську, відомого дослідник рекре ційного комплексу кр їнських рп т, втор моногр фії “екре ционн я систем оветских рп т” (1983). же серед дипломних робіт студентів першого випуску к федри (1994) були пр ці рекреційно-туристичного спрямув ння. ьогодні в цьому н прямі пр цюють передусім . тецюк і . озинський.

2002-2005 рр. викл д чі к федри бр ли уч сть в проекті PAUCI ( ольсько- мерик нсько-укр їнськ ініці тив про співпр цю, іiі пр вон ступник - ольсько-укр їнськ фунд ція співпр ці) “ уристичний потенці л хідної кр їни: н прямки і можливості інвестицій в секторі туризму з використ нням польського досвіду”, який виконув ли спільно колектив н уковців нституту туризму у рш ві, геогр фічного ф культету ьвівського н ціон льного університету імені в н $\mathrm{p}$ нк, иївського університету туризму, економіки і пр в . . озинський є спів втором н укової моногр фії, опубліков ної з результ т ми проекту ("Potencjal turystyczny Ukrainy Zachodniej", Warszawa, 2005).

уризмозн вчі дослідження є головним пріоритетом н укових досліджень . тецюк, як м є зн чний ст ж пр ктичної роботи в г лузі туризму. 2002 р. . тецюк відповідно до н к зу голови ерж вної туристичної дміністр ції кр їни присвоєно зв ння “ очесний пр цівник туризму кр їни”. он пройшл професійні ст жув ння в ерж вній туристичній дміністр ції кр їни, в юро з пит нь освіти т культури ерж вного деп рт менту (вивчення мерик нського досвіду у сфері туризму і рекре ції), н к федрі туризму кономічного університету в р кові т у відділі промоції міської р ди м. р ков ( еспублік ольщ ), бр л уч сть у ре ліз ції різном нітних міжн родних проектів з розвитку рекре ційно-туристичної г лузі хідного регіону кр їни. 2008 р. . тецюк у спів вторстві з доцентом к федри туризму . утинським опублікув л н вч льний посібник “ узеєзн вство” для студентів спеці льності “туризм” т моногр фію “ уристичний комплекс рп тського регіону кр їни”.

. озинський впродовж б г тьох років був членом журі сеукр їнської студентської олімпі ди зі спеці льності “туризм” т сеукр їнського конкурсу студентських н укових робіт з н пряму “туризм”.

еогр фічне кр єзн вство. озвиткові цього н пряму к федр передусім з вдячує відомому укр їнському етногр фові, геогр фу-кр єзн вцю, л уре ту сеукр їнської премії ім. . убинського . нилюку (1941-2008). ін здійснив експедиції до сотень сіл кр їни, пон д 30 років пр цюв в у узеї н родної рхітектури т побуту у ьвові, зібр в зн чну ч стку його експон тів [1].

життя . нилюк н пис в пон д 500 н укових пр ць: моногр фій, довідників, ст тей у н укових збірник х т журн л х. йвідоміші з його моногр фій: “ оклонись н родному зодчому: тногр фічні н риси про н родну рхітектуру кр їни” ( ьвів, 1995), “ елікти д внього будівництв . м'ятки н родної рхітектури івненського олісся” ( івне, 1995), “ олинь: п м’ятки н родної рхітектури” ( уцьк, 2000), “ к рби н родно рхітектури уцульщини” ( ьвів, 2000), “р диційн рхітектур регіонів кр їни: олісся” ( ьвів, 2001), “ родн рхітектур олинського олісся” ( уцьк, 2002), “ глини, дерев і соломи. м'ятки н родної рхітектури хідного оділля” 
( ернопіль, 2003), “ лях ми кр їни. тногр фічний н рис” ( ьвів, 2003), “ родн рхітектур ойківщини” ( ьвів, 2004 “ кр їнські ск нсени. сторія виникнення експозиції, проблеми розвитку” ( ернопіль, 2007), “р ми ьвівського ск нсену” ( ьвів, 2007).

ьогодні кр єзн вчі дослідження н к федрі продовжує . врук, у 2011 р. вон підготув л до друку моногр фію “ овом лин у просторі і ч сті: кр єзн вче дослідження укр їнського сел ".

еогр фія н селення і геогр фія поселень. ей н прям є тр диційним для к федри геогр фії кр їни. ін з поч тков ний, як з зн чено, . ст вним ще у 90-х рок х ст., коли в серії “ родозн вчі студіі” опубліков но його моногр фію “ селення кр їни”. к федрі геогр фії кр їни з демогеогр фічної проблем тики 3 хищено три дисерт ції, опубліков но декільк моногр фій і н вч льних посібників. уч сні н укові дослідження . суляк присвячені демогр фічним проблем м укр їнськопольського погр ниччя. бінськ пов'язує демогеогр фічну проблем тику з генерними проблем ми. . ністрянськ досліджує демогеогр фічні проблеми функціонув ння селищ міського типу.

сього 321 рік існув ння к федри геогр фії кр їни її викл д чі опублікув ли близько 60 моногр фій, підручників, н вч льних посібників і брошур, декільк сотень н укових ст тей в укр їнських і з рубіжних вид ннях.

ьогодні к федр геогр фії кр їни вирізняється н ф культеті високою кв ліфік цією викл д цького скл ду, усі її викл д чі м ють н уковий ступень к ндид т бо доктор н ук, вчене зв ння професор, доцент бо пр цюють н пос д х доцент .

еред пріоритетів діяльності к федри н н йближчі роки передусім потрібно виділити т кі:

1) поглиблення досліджень з тр диційних для к федри н прямів геогр фічних досліджень: етнічн геогр фія, політичн геогр фія і геополітик , геогр фія туризму, передусім, н пис ння пр ць, що м ють теоретичне спрямув ння.

2) розвиток нових н прямів геогр фічних досліджень: соці льн геогр фія, геогр фія культури, медичн геогр фія;

3) удоскон лення н вч льних прогр м, підготовк нових н вч льно-методичних пр ць, н вч льних посібників і підручників з норм тивних дисциплін т спецкурсів, які к федр пропонує студент м;

4) інтенсифік ція міжн родних н укових зв'язків, збільшення кількості публік цій в вторитетних іноземних вид ннях, ктивіз ція уч сті пр цівників к федри в н укових конференціях, що відбув ються з кордоном.

1. утинський . . уков етногеогр фічн сп дщин, внесок т підходи до збереження н ціон льного енокультурного різном ніття рхип нилюк / . утинський // сторія укр їнської геогр фії. сеукр. н ук.-теор. ч сопис. - ернопіль : ідручники і посібники, 2008. - ип. 17. $-.127-134$ 


\section{DEPARTMENT of GEOGRAPHY of UKRAINE at IVAN FRANKO NATIONAL UNIVERSITY of LVIV: FOUNDATION, STAGES of DEVELOPMENT, DIRECTIONS of SCIENTIFIC STUDIES}

\section{R. Lozynskyy}

Ivan Franko National University of Lviv,

. Doroshenko St., 41, UA - 79000 Lviv, Ukraine, tel. 239-47-69

The article describes the foundation and development of the Department of Geography of Ukraine at Ivan Franko National University of Lviv. It was the firs of the kind in Ukraine. There are four stages delineated in its development. The current state is analysed, its gains and the most important research topics.

Key words: geography, Department of Geography of Ukraine, stages of development, direction research

\section{- озинский}

ввовский н цион льный университет имени в н

ул. . орошенко, 41, г. ввов, 79000, кр ин, тел. 239-47-69

пис но ст новление и р звитие к федры геогр фии кр ины ьвовского н цион льного университет имени в н р нко, первой к федры т кого н пр вления 3 всю истории существов ния р зных геогр фических институций в кр ине. ыделено и ох р ктеризов но четыре эт п в р звитии к федры геогр фии кр ины. ро н лизиров но современное состояние к федры, ее гл вные н учные достижения, т кже в жнейшие н пр вления н учных исследов ний.

лючевые слов : геогр фия, к федр геогр фии кр ины, эт пы р звития, н пр вления н учных исследов ний. 